\title{
Upaya Pemerintah Desa dalam Penanganan Persebaran Covid-19 : Studi pada Desa Ngestiharjo, Kapanewon Kasihan, Bantul
}

\author{
Ilham Danni Putera ${ }^{1}$; Isnaini Mu'allidin ${ }^{2}$ \\ ${ }^{1,2}$ Program Studi Ilmu Pemerintahan, Universitas Muhammadiyah Yogyakarta, \\ danniilham27@gmail.com
}

\begin{abstract}
Abstrak
Penelitian ini bertujuan untuk menganalisis bagaimana penanganan yang dilakukan oleh Pemerintah Desa di Desa Ngestiharjo dalam upaya untuk menekan serta menghentikan laju penyebaran Virus Corona yang meluas di masyarakat. Metode penelitian kualitatif deskriptif digunakan dalam penelitian ini dengan variabel penelitian yaitu mitigasi (Mitigation), pencegahan (Prevention), serta kesiapan (Preparedness) dan peringatan dini (Early Warning) (Ramli, 2010). Responden yang dipilih oleh peneliti yaitu satgas Covid19, pemdes, BPBD Bantul dan masyarakat Desa Ngestiharjo. Hasil penelitian menunjukkan bahwa upaya Pemerintah Desa Ngestiharjo dalam penanganan persebaran Covid-19 masih belum maksimal walaupun telah melakukan berbagai macam upaya mitigasi seperti pembuatan shelter serta Peraturan Pemerintah Desa. Pencegahan dari Pemerintah Desa Ngestiharjo berupa pelatihan penggunaan alat pelindung diri dan pemakaman dengan protokol kesehatan. Kesiapan Pemerintah Desa Ngestiharjo ditunjukan melalui koordinasi dengan pihak-pihak terkait serta Kepala Pedukuhan yang saling bekerja sama, namun untuk peringatan dini dari Pemerintah Desa Ngestiharjo belum terlaksana, dikarenakan belum ada metode dan peralatan yang sesuai untuk bencana Pandemi Covid19, mengingat bencana non-alam tersebut baru pertama kali terjadi.
\end{abstract}

Kata kunci : Pandemi Covid-19, Pemerintah Desa Ngestiharjo, Penanganan

\begin{abstract}
This research aims to analyze how the handling was carried out by the Village Government in Ngestiharjo Village in an effort to suppress and stop the rate of spread of coronavirus that is widespread in the community. Descriptive qualitative research methods are used in this study with research variables namely mitigation, prevention, and readiness (Preparedness) and early warning (Ramli, 2010). Respondents selected by the researchers were the Covid-19 task force, the government, BPBD Bantul and the ngestiharjo village community. The results showed that the efforts of the Ngestiharjo Village Government in handling the spread of Covid-19 are still not maximal despite various mitigation efforts such as shelter making and Village Government Regulations. Prevention from the Ngestiharjo Village Government in the form of training in the use of personal protective equipment and funerals with health protocols. The readiness of the Ngestiharjo Village Government is demonstrated through coordination with relevant parties and the Head of Support who cooperates with each other, but for early warning from the Ngestiharjo Village Government has not been implemented, because there are no suitable methods and equipment for the Covid-19 Pandemic disaster, considering that the non-natural disaster has only occurred for the first time.
\end{abstract}

Keywords: Covid-19 Pandemic, Handling, Ngestiharjo Village Government 


\section{Pendahuluan}

Covid-19 atau Coronavirus Diseases 2019 merupakan wabah penyakit yang melanda dunia yang baru pertama kali terjadi dan belum pernah diidentifikasi sebelumnya (Dewi, 2020). Pada awal kemunculan Covid-19, belum ditemukan vaksin atau obat untuk orang-orang yang terinfeksi Covid-19, namun seiring dengan berjalannya waktu, banyak peneliti dari berbagai negara membuat komitmen untuk menciptakan vaksin Covid-19 dengan bekerjasama dengan berbagai pihak mulai dari pemerintah, ilmuwan, perusahaan-perusahaan bioteknologi, sampai dengan akademisi (Makmun \& Hazhiyah, 2020). Penelitian yang dilakukan juga memerlukan waktu yang tidak sebentar dan dana yang besar mengingat kebutuhan vaksin yang mendesak dan banyak pihak yang terlibat dalam penelitian (Sari \& Sriwidodo, 2020), sehingga diperlukan upaya-upaya antisipasi dan pencegahan sembari menunggu ditemukannya vaksin Covid-19. Indonesia menjadi salah satu negara yang terdampak Covid-19 dengan total kasus Covid-19 sebanyak 470.000 kasus terkonfirmasi positif sejak virus tersebut terdeteksi masuk ke Indonesia pada bulan Maret hingga pertengahan November 2020 dan hampir 1 Juta kasus positif pada awal tahun 2021 dengan jumlah kematian sebesar 29.000 (Akbar, 2021). Sebagai negara yang juga terdampak Covid-19, Pemerintah Indonesia melakukan langkah antisipasi penyebaran virus untuk mengurangi penularan dan jatuhnya korban jiwa akibat Covid-19 dengan cara memberlakukan kebijakan PSBB (Pembatasan Sosial Berskala Besar) dengan membatasi aktifitas diluar rumah seperti bekerja, sekolah, beribadah dan kegiatan lain yang membuat orang-orang berkerumun (Nasruddin \& Haq, 2020). Hampir semua kegiatan masyarakat juga dibatasi dan diharuskan menerapkan protokol kesehatan dalam setiap aktivitas sehari-hari seperti mencuci tangan secara teratur, menjaga jarak, memakai masker dan meningkatkan daya tahan tubuh. Pembatasan ini sebagai salah satu upaya pencegahan dalam penanganan Covid 19 (Handayani et al., 2020).

Penjelasan terkait dengan PSBB (Pembatasan Sosial Berskala Besar) diatur di dalam Undang-Undang No. 6 tahun 2018 Bab VII Pasal 59 (Telaumbanua, 2020), yang menyebutkan bahwa Pembatasan Sosial Berskala Besar (PSBB) merupakan bagian dari respons Kedaruratan Kesehatan Masyarakat yang memiliki 
tujuan untuk mencegah meluasnya penyebaran penyakit menular yang sedang terjadi antar orang di suatu wilayah tertentu. PSBB diterapkan di beberapa lingkup dalam jangka waktu tertentu, seperti penutupan sekolah dan tempat kerja, pembatasan kegiatan keagamaan di tempat ibadah, dan pembatasan kegiatan yang berpotensi mendatangkan keramaian atau kerumunan. Penyelenggaraan PSBB juga berkoordinasi dan bekerjasama dengan berbagai instansi atau pihak-pihak terkait berdasarkan peraturan yang sudah ditetapkan.

Selain itu, untuk menjaga stabilitas keuangan negara selama Pandemi Covid-19 sekaligus membantu masyarakat miskin yang terdampak Covid-19, Pemerintah Pusat melalui Kementerian Desa, Pembangunan Daerah Tertinggal, dan Transmigrasi melakukan perubahan kedua terhadap Permendes yang sebelumnya Permendes Nomor 11 tahun 2019 tentang Prioritas Pembangunan Dana Desa tahun 2020 menjadi Permendes Nomor 7 tahun 2020 yang menjelaskan prioritas penggunaan dana desa terutama saat terjadi bencana alam dan non-alam (Kementerian Desa, Pembangunan Daerah Tertinggal, dan Transmigrasi, 2020). Bencana non-alam yang dimaksud adalah penyakit menular, yang mana dalam Permendes ini dijelaskan mengenai bencana non-alam yang menyebabkan kejadian luar biasa dan mengancam keselamatan masyarakat secara luas. Pada perubahan kedua Permendes ini ditambahkan Pandemi Coronavirus Disease 2019 (Covid-19) sebagai penyakit menular yang mengancam keselamatan masyarakat, serta dilakukan perubahan dan perpanjangan pada prioritas penggunaan dana desa dalam hal ini Bantuan Langsung Tunai Dana Desa (BLT DD) yang diperuntukkan untuk masyarakat yang miskin.

Covid-19 yang menjadi pandemi juga menyebar ke berbagai wilayah di Indonesia, tanpa terkecuali di DIY, yang sampai dengan 23 September 2020 terdapat 2.312 kasus terkonfirmasi positif dengan 1.578 orang sembuh dan 60 orang meninggal dunia. Sementara itu, di Kabupaten Bantul DIY, terdapat 674 kasus dengan jumlah kematian mencapai 18 orang (Dinas Kesehatan Kabupaten Bantul, 2020). Semakin mewabahkan Covid-19 juga mendorong Pemerintah Daerah untuk membuat dan mengeluarkan kebijakan yang bertujuan untuk mengurangi kegiatan masyarakat yang berpotensi menularkan virus guna menghambat penyebaran virus 
lebih meluas dan mengurangi jatuhnya korban jiwa. Selain pemerintah, masyarakat juga berperan aktif dalam berbagai upaya untuk mengurangi penyebaran virus, seperti yang dilakukan masyarakat di desa-desa di DIY, dimana banyak yang melakukan penutupan jalan atau akses keluar masuk desanya dan melarang orang yang bukan penduduk asli desa tersebut untuk memasuki desa (Subarkah, 2021). Tindakan ini menjadi salah satu tindakan antisipasi masyarakat di desa-desa dengan mencegah orang dari luar desa masuk ke desa, karena dikhawatirkan orang tersebut membawa virus dan menularkannya ke masyarakat di desa tersebut.

Kasus Covid-19 juga ditemukan di Desa Ngestiharjo, Kapanewon Kasihan, Kabupaten Bantul, dimana jumlahnya tidak sedikit dan cenderung meningkat. Jumlah kasus Covid-19 di Desa Ngestiharjo terhitung sejak awal Covid19 dengan Pedukuhan Sonopakis Lor yang menjadi wilayah dengan persebaran tertinggi dibanding wilayah lain dengan jumlah sembuh sebanyak 49 orang dan 3 lainnya meninggal. Total kasus di setiap pedukuhan yang tertular Covid-19 mencapai 350 orang, 7 diantaranya meninggal dunia dan 333 orang lainnya sembuh (Pemerintah Desa Ngestiharjo, 2020). Dengan jumlah yang tidak sedikit tersebut, kemudian menuntut Pemerintah Desa Ngestiharjo untuk memikirkan dan melakukan upaya-upaya penanganan agar Covid-19 tidak semakin menyebar sekaligus mengurangi dampak yang lebih buruk lagi. Pemerintah desa sebagai pemerintahan terendah yang langsung berhadapan dengan masyarakat diharapkan dapat membantu dan bekerjasama dengan pemerintah pusat dalam melakukan upaya-upaya penanganan Covid-19, sekaligus menjadi salah satu strategi yang efektif dan efisien dalam pelaksanaan percepatan pengendalian persebaran Covid19 di Indonesia (Salman et al., 2021).

Jika pada penelitian sebelumnya, banyak pemerintah desa berfokus pada penanganan ekonomi desa dan pendapatan masyarakat akibat adanya Pandemi Covid-19, seperti penelitian (Sasuwuk et al., 2021) yang membahas implementasi kebijakan penyaluran BLT-DD pada masa Pandemi Covid-19 di Desa Sea, Kabupaten Minahasa, kemudian penelitian oleh (Fanisa \& Ma'ruf, 2021) dan (Pamungkas et al., 2020) yang membahas pemanfaatan dana desa pada masa Pandemi Covid-19 untuk warga terdampak di Desa Bohar, Kabupaten Sidoarjo dan 
desa di Kabupaten Sumbawa, maka pada penelitian ini akan lebih berfokus pada upaya-upaya yang dilakukan Pemerintah Desa Ngestiharjo, Kecamatan Kasihan, Kabupaten Bantul dalam penanganan persebaran Coronavirus Disaster (Covid-19), tidak hanya di bidang ekonomi tetapi juga dibidang lain terutama dalam rangka penanganan dampak yang ditimbulkan dan untuk mengurangi persebaran virus yang lebih luas. Analisis dilakukan dengan menggunakan variabel penelitian yaitu mitigasi (Mitigation), pencegahan (Prevention), serta kesiapan (Preparedness) dan peringatan dini (Early Warning) (Ramli, 2010).

\section{Metode}

Penelitian dilakukan di Desa Ngestiharjo, Kapanewon Kasihan, Kabupaten Bantul DIY dengan menggunakan metode penelitian kualitatif deskriptif. Penelitian kualitatif digunakan untuk menemukan sekaligus mengumpulkan jawaban dari narasumber atau responden untuk menjawab permasalahan-permasalahan yang sedang diteliti (Subandi, 2011). Kemudian, datadata yang telah diperoleh, dideskripsikan untuk memperjelas jawaban atas permasalahan agar mempermudah pembaca dalam memahami hasil penelitian (Gumilang, 2016). Data penelitian diperoleh dari hasil wawancara, observasi dan studi literatur dengan responden yang berasal dari satgas Covid-19, BPBD Bantul dan pemerintah desa serta masyarakat Desa Ngestiharjo. Data-data yang berasal dari hasil penelitian kemudian diolah melalui tahap reduksi data, interpretasi, penyajian data dan kemudian dilakukan penarikan kesimpulan (Moleong, 2017). Data-data yang berasal dari hasil penelitian kemudian diolah melalui tahap reduksi data, interpretasi, penyajian data dan kemudian dilakukan penarikan kesimpulan ( Moleong, 2017; Sudirman et al., 2021; Sudirman \& Rifai, 2021).

\section{Hasil dan Pembahasan}

Munculnya pandemi Covid-19 yang melanda seluruh dunia memberikan dampak yang buruk dan mempengaruhi banyak aktifitas masyarakat, yang kemudian mendorong pemerintah mencari cara penanganan yang tepat terhadap Covid-19, karena negara menjamin keselamatan dan kesehatan rakyatnya. Dalam 
Undang-undang Dasar 1945 Pasal 28 H Ayat 1 disebutkan bahwa setiap orang berhak hidup sejahtera lahir dan batin, bertempat tinggal dan mendapatkan lingkungan hidup yang baik dan sehat serta berhak memperoleh pelayanan kesehatan. Dalam Pasal 34 Ayat 3 juga disebutkan bahwa negara bertanggung jawab terhadap penyediaan fasilitas pelayanan kesehatan dan fasilitas pelayanan umum yang layak.

Kebijakan dan bantuan tersebut kemudian diteruskan dari Pemerintah Pusat kepada Pemerintah Daerah dan Pemerintah Desa agar dijalankan dengan baik dan tepat sasaran. Pemerintah Desa terutama Desa Ngestiharjo bergerak cepat dalam menjalankan amanah tersebut dengan mengambil berbagai tindakan agar kebijakan dan bantuan yang diberikan berjalan lancar sebagai langkah penanganan persebaran Covid-19 dan mengurangi dampak yang disebabkan, oleh karena itu untuk mengetahui bagaimana penanganan persebaran Covid-19 di Desa Ngestiharjo, digunakan beberapa variabel dalam melakukan penelitian, yaitu sebagai berikut

\section{Mitigasi (Mitigation)}

Mitigasi dalam Undang-Undang Nomor 24 tahun 2007 tentang Penanggulangan Bencana adalah serangkaian upaya yang dilakukan untuk mengurangi resiko dari suatu bencana yang dapat dilakukan melalui pembangunan fisik maupun penyadaran dan peningkatan kemampuan dalam menghadapi potensi bencana (Putra, 2014). Tujuan dari mitigasi bencana ialah:

1. Mengurangi resiko kerugian yang ditimbulkan saat terjadinya bencana terutama terhadap keselamatan masyarakat baik korban jiwa, kerugian materi, serta kerusakan sumber daya alam.

2. Sebagai pedoman atau dasar perencanaan pembangunan berkelanjutan

3. Meningkatkan kemampuan dan kepekaan masyarakat dalam menghadapi dan mengurangi resiko yang ditimbulkan dari bencana.

Beberapa kegiatan mitigasi yang dilakukan oleh Pemerintah Desa Ngestiharjo sebagai upaya pencegahan persebaran Covid-19 yaitu sebagai berikut: 


\section{a. Rapat Koordinasi dan Sosialisasi}

Pemerintah Desa Ngestiharjo bekerja sama dengan masyarakat Desa Ngestiharjo melakukan berbagai macam bentuk mitigasi secara non-struktural. Mengingat Pandemi Covid-19 merupakan kejadian yang pertama kali bagi pemerintah desa dan masyarakat Desa Ngestiharjo, Dedy Ridwanmas sebagai Sekretaris Desa Ngestiharjo mengungkapkan bahwa langkah awal yang dilakukan oleh Pemerintah Desa Ngestiharjo yaitu dengan melakukan rapat koordinasi guna menentukan langkah yang tepat untuk mengatasi masalah persebaran Covid-19 di wilayah Desa Ngestiharjo.

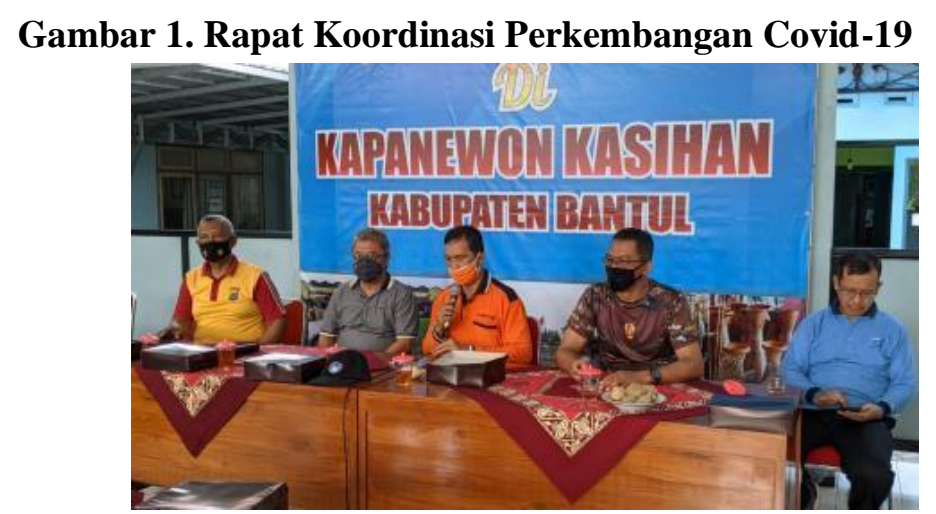

Sumber: Website Pemerintah Desa Ngestiharjo (2020)

Rapat koordinasi tersebut membahas mengenai perkembangan dan persebaran Covid-19 di wilayah Desa Ngestiharjo dengan mengundang dan bekerja sama dengan pihak kepolisian serta Badan Penanggulangan Bencana Daerah Kabupaten Bantul. Dari rapat tersebut, dihasilkan kesepakatan untuk melakukan sosialisasi kepada masyarakat, yaitu dengan memberikan edukasi dan pengenalan apa itu Covid-19 sampai dengan pencegahan terhadap Covid-19. Kegiatan tersebut bertujuan untuk memberikan pemahaman kepada masyarakat terkait adanya Pandemi Covid-19, sehingga masyarakat menjadi lebih mengerti dan tahu tindakan apa yang harus dilakukan terhadap Covid-19 tersebut. Pemerintah Desa Ngestiharjo juga lebih memfokuskan sosialisasi Covid-19 melalui selebaran, edaran, dan juga media sosial seperti whatsapp dan facebook, serta melalui kepala pedukuhan yang kemudian disampaikan langsung kepada masyarakat sekitar. Sosialisasi dan edukasi yang dilakukan juga sebagai salah satu cara untuk membangun sumber 
daya manusia, karena pembangunan SDM (masyarakat) dirasa efektif dan efisien untuk saat itu, karena anggaran pemerintah desa yang juga terbatas. Respon yang ditunjukkan masyarakat Desa Ngestiharjo terhadap sosialisasi yang dilakukan juga cukup baik, dimana masyarakat mulai aktif melaksanakan anjuran pemerintah desa, seperti mulai memperhatikan kebersihan diri, menggunakan masker, mematuhi protokol kesehatan, dan sadar mengenai dampak serta hal yang perlu dilakukan dalam penanganan persebaran Covid-19.

\section{b. Pembuatan Peraturan Terkait Covid-19}

Pemerintah Desa Ngestiharjo juga mengeluarkan peraturan sebagai upaya mengurangi persebaran Covid-19 di Desa Ngestiharjo melalui Surat Edaran Nomor 440/100 Tentang Himbauan Pencegahan Penularan Infeksi Covid-19 yang berisi

1) Jam pelayanan di Desa Ngestiharjo dari pukul 08.00-12.00 WIB

2) Dilarang mengadakan kegiatan yang menyebabkan kerumunan dalam jumlah banyak ditempat umum maupun di tempat sendiri diantaranya:

a) Kegiatan sosial, budaya, dan aliran kepercayaan

b) Pasar malam, festival, perlombaan, pameran, hajatan, dan sejenisnya

c) Menghimbau masyarakat untuk menjaga kebersihan dan melakukan penyemprotan disinfektan mandiri

Surat edaran yang dikeluarkan Kepala Desa Ngestiharjo ditujukan untuk mengurangi kegiatan masyarakat Ngestiharjo agar persebaran Covid-19 berkurang dan aturan tersebut berlaku sampai kondisi dapat dikendalikan seperti sedia kala. Selain Surat Edaran yang dikeluarkan oleh Pemerintah Desa Ngestiharjo, ada pula peraturan yang dibuat sendiri dan diterapkan oleh masyarakat Desa Ngestiharjo, yaitu dengan membatasi dan menjaga akses keluar masuk perkampungan, agar orang-orang selain masyarakat Desa Ngestiharjo tidak sembarangan masuk desa, karena dikhawatirkan membawa virus ke Desa Ngestiharjo. Masyarakat Desa Ngestiharjo yang keluar masuk pun diwajibkan memakai masker dan disemprotkan desinfektan saat akan memasuki perkampungan, mencuci tangan atau menggunakan hand sanitizer yang sudah disediakan. Jika ada orang selain warga kampung yang akan masuk ke Desa Ngestiharjo, baik orang dari luar maupun masyarakat setempat yang melakukan perjalanan dari luar daerah, maka diwajibkan 
membawa hasil tes kesehatan serta melakukan isolasi mandiri secara 7-14 hari. Hal tersebut merupakan inisiatif dari masyarakat di setiap pedukuhan Ngestiharjo tanpa adanya keterlibatan dari Pemerintah Desa Ngestiharjo. Pemerintah Desa Ngestiharjo turut mengapresiasi usaha dari masyarakat Desa Ngestiharjo dalam menangani dan menanggulangi penyebaran Covid-19.

\section{c. Pembangunan Posko Covid-19}

Pemerintah Desa Ngestiharjo juga membangun posko Covid-19 di lingkungan kantor Pemerintah Desa Ngestiharjo yaitu posko Pemberlakuan Pembatasan Kegiatan Masyarakat Mikro atau PPKM Mikro. Pembangunan posko tersebut merupakan tindak lanjut dari Pemerintah Desa Ngestiharjo dalam menyiapkan materi dan informasi yang dibutuhkan dalam rangka penanggulangan Covid-19.

\section{Gambar 2. Posko PPKM Mikro Desa Ngestiharjo}

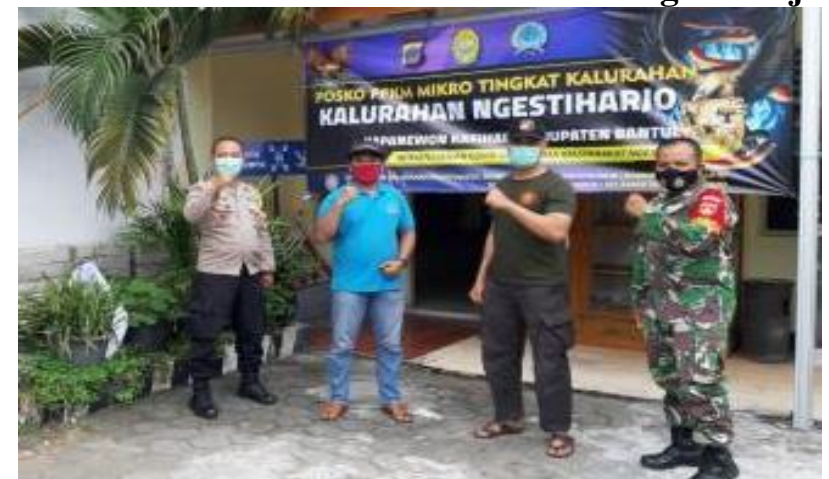

Sumber: Website Pemerintah Desa Ngestiharjo (2021)

Posko ini juga memberikan informasi terkait perkembangan Covid-19 di wilayah Desa Ngestiharjo dari tingkat RT, Padukuhan, dan Desa. Fungsi dari posko PPKM Mikro adalah sebagai pendukung komunikasi, logistik serta administrasi. Posko ini juga sebagai bagian dari sosialisasi penerapan 5M yaitu memakai masker, mencuci tangan, menjaga jarak, menjauhi kerumunan, dan membatasi mobilisasi, serta melakukan penegakan disiplin terhadap protokol kesehatan seperti pembatasan kerumunan serta turut berperan dalam memperkuat solidaritas masyarakat dalam menangani persebaran Covid-19.

\section{d. Pengelolaan Dana Desa}

Semenjak diberlakukannya PPKM (Pemberlakuan Pembatasan Kegiatan Masyarakat) pada bulan Februari, Pemerintah Kabupaten dan juga Kementerian 
Kesehatan meminta untuk mengoptimalkan Dana Desa, dalam hal ini Pemerintah Desa Ngestiharjo membuat shelter atau tempat untuk melakukan karantina dan isolasi mandiri bagi pasien Covid-19. Shelter tersebut harus dilengkapi dengan fasilitas, sarana dan prasarana penunjang isolasi bagi masyarakat (Gugus Tugas Covid-19, 2020). Shelter di Desa Ngestiharjo merupakan Puskesmas Pembantu milik Puskesmas Kasihan II yang terletak di pedukuhan Kadipiro Selatan, namun belum sepenuhnya digunakan, karena masyarakat yang positif Covid-19 lebih memilih untuk melakukan isolasi mandiri di rumah masing-masing.

Dana desa juga digunakan untuk membantu masyarakat miskin yang terdampak Covid-19 melalui pemberian BLT DD (Bantuan Langsung Tunai Dana Desa). Bantuan ini diberikan oleh pemerintah desa sebagai perpanjangan tangan dari pemerintah pusat yang mengacu pada Permendes dan Permendagri. Dijelaskan di dalam Permendes Nomor 6 Tahun 2020 Pasal 8A bahwa sasaran penerima BLT DD merupakan keluarga miskin yang terdampak Covid-19 yang kehilangan mata pencaharian atau pekerjaan, belum terdata menerima Program Keluarga Harapan (PKH), Bantuan Pangan Non Tunai (BPNT), dan kartu pra kerja, serta yang mempunyai anggota keluarga yang rentan sakit menahun/kronis. Nilai bantuan yang diberikan yaitu sebesar Rp 600.000 setiap bulan selama 3 bulan bagi mereka yang memenuhi syarat. Pada 3 bulan berikutnya, akan mendapat Rp 300.000 secara berkala dalam waktu 6 bulan, dan terhitung sejak bulan April dan dapat disalurkan sepanjang dana desa tahun anggaran 2020 masih tersedia, sesuai dengan Peraturan Menteri Desa, Pembangunan Daerah Tertinggal dan Transmigrasi Nomor 7 Tahun 2020 Tentang Perubahan Kedua Atas Peraturan Menteri Desa, Pembangunan Daerah Tertinggal, dan Transmigrasi Nomor 11 Tahun 2019 (Sasuwuk et al., 2021).

Namun dalam pelaksanaannya, Pemerintah Desa Ngestiharjo menemui masalah, dimana Pemerintah Desa Ngestiharjo mengalami kekurangan dana dalam pelaksanaanya, karena di awal tahun sudah digunakan untuk belanja anggaran terlebih dahulu dibandingkan dengan pembagian BLT DD, sehingga terpaksa memangkas dana kas Desa Ngestiharjo atau melakukan pinjaman untuk dana yang tidak terduga atau berlebih. Pemerintah Kabupaten sendiri tidak memberikan dana pengganti untuk kejadian tersebut. Berikut rincian APBDes Ngestiharjo 
Tabel 2. APBDes Ngestiharjo Tahun 2020 untuk Covid-19

\begin{tabular}{|c|c|c|c|c|c|c|}
\hline \multirow{2}{*}{\begin{tabular}{|l|} 
KODE \\
REKK \\
\end{tabular}} & \multirow{2}{*}{\multicolumn{2}{|c|}{ URAIAN }} & ANGGARAN & REALISASI & LEBIH/(KURANG & KETERANGAN \\
\hline & & & $(\mathrm{Rp})$ & $|R p|$ & $(\mathrm{Rp})$ & \\
\hline 1 & & 2 & 3 & 4 & 5 & 6 \\
\hline 531 & \multicolumn{2}{|c|}{ Penanganan Keadaan Mendesak } & $774.900 .000,00$ & $772.500 .000,00$ & $2.400 .000,00$ & \\
\hline \multirow[t]{10}{*}{531} & 00 & Belanja Tidak Terduga & $774.900 .000,00$ & $772.500 .000,00$ & $2.400 .000,00$ & - BLT DD tahap 1-9 \\
\hline & & & & & & $\begin{array}{l}\text { Tahap 1:273 KPM @ 600.000 } \\
=163.800 .000\end{array}$ \\
\hline & & & & & & $\begin{array}{l}\text { Tahap 2:273 KPM @ 600.000 } \\
=163.800 .000\end{array}$ \\
\hline & & & & & & $\begin{array}{l}\text { Tahap 3:273 KPM @ 600.000 } \\
=163.800 .000\end{array}$ \\
\hline & & & & & & $\begin{array}{l}\text { Tahap } 4: 293 \text { KPM @ } 300.000 \\
=87.900 .000\end{array}$ \\
\hline & & & & & & $\begin{array}{l}\text { Tahap } 5: 293 \mathrm{KPM} @ 300.000 \\
=87.900 .000\end{array}$ \\
\hline & & & & & & $\begin{array}{l}\text { Tahap 6:291 KPM @ } 300.000 \\
=87.300 .000\end{array}$ \\
\hline & & & & & & $\begin{array}{l}\text { Tahap 7: } 20 \mathrm{KPM} @ 300.000 \\
=\quad 6.000 .000\end{array}$ \\
\hline & & & & & & $\begin{array}{l}\text { Tahap 8: } 20 \mathrm{KPM} @ 300.000 \\
=\quad 6.000 .000\end{array}$ \\
\hline & & & & & & $\begin{array}{l}\text { Tahap 9: } 20 \mathrm{KPM} @ 300.000 \\
=6.000 .000\end{array}$ \\
\hline 511 & \multicolumn{2}{|c|}{ Kegiatan Penanggulanan Bencana } & $272.643 .500,00$ & $265.320 .000,00$ & $7.323 .500,00$ & \\
\hline 511 & 00 & Belanja Barang dan Jasa & $37.125 .000,00$ & $29.860 .000,00$ & $7.265 .000,00$ & $\begin{array}{l}\text { Operasional Penanggulangan } \\
\text { Bencana dan Covid } 19\end{array}$ \\
\hline 511 & 00 & Belanja Tidak Terduga & $235.518 .500,00$ & $235.460 .000,00$ & $58.500,00$ & $\begin{array}{l}\text { Operasional Penanggulangan } \\
\text { Bencana dan Covid } 19\end{array}$ \\
\hline & & & $1.047 .543 .500,00$ & $1.037 .820 .000,00$ & $9.723 .500,00$ & \\
\hline
\end{tabular}

Tabel di atas menunjukan dana dari Pemerintah Desa yang diperuntukan untuk Bantuan Langsung Tunai Dana Desa yang dikeluarkan secara bertahap sampai tahap ke-9. Dana yang dikeluarkan Pemerintah Desa Ngestiharjo untuk BLT-DD sebanyak Rp 772.500.000 dan ada dana lebih sebanyak Rp 2.400.000 dari yang dianggarkan yaitu Rp 774.900.000. Dana untuk kegiatan penanggulangan bencana yang dianggarkan sebanyak Rp 272.243.500 dan yang berhasil terealisasi sebanyak Rp 265.320.000 sehingga menyisakan dana sebanyak Rp 7.323.500. Dana kegiatan penanggulangan bencana diperuntukan untuk penggunaan shelter, pembelian alat kesehatan, sosialisasi dan lainnya yang dirasa oleh Pemerintah Desa Ngestiharjo berguna untuk penanggulangan bencana Covid-19 di Ngestiharjo.

\section{Pencegahan (Prevention)}

Pencegahan adalah suatu langkah yang dilakukan untuk mencegah suatu kejadian agar tidak terjadi. Dalam hal pencegahan Covid-19, pemerintah pusat memberlakukan Pembatasan Sosial Berskala Besar (PSBB) dalam rangka percepatan penanganan Covid-19 berdasarkan Peraturan Pemerintah Nomor 12 tahun 2020 tentang tindakan pencegahan Covid-19 dan harus dilakukan oleh semua elemen masyarakat tanpa terkecuali agar mencegah penularan Covid-19 di tengahtengah masyarakat. Pemerintah Desa Ngestiharjo juga melakukan berbagai macam 
pencegahan untuk mengurangi persebaran Covid-19 yang terjadi di wilayah Desa Ngestiharjo. Beberapa kegiatan pencegahan yang dilakukan oleh Pemerintah Desa Ngestiharjo sebagai upaya pencegahan persebaran Covid-19 yaitu sebagai berikut:

\section{a. Pelatihan Kepada Relawan Covid-19}

Guna mencegah persebaran, Pemerintah Desa Ngestiharjo memberikan pelatihan yang ditujukan kepada masyarakat Desa Ngestiharjo terutama kepada relawan Covid-19. Pelatihan yang dilakukan Pemerintah Desa Ngestiharjo merupakan salah satu Protokol Penanganan Covid-19 yang harus diterapkan oleh relawan-relawan Covid-19 di setiap pedukuhan di Desa Ngestiharjo. Dalam pelatihan tersebut para relawan Covid-19 diajarkan untuk memakai perlengkapan Alat Pelindung Diri (APD) secara baik dan benar yang sesuai dengan Protokol Kesehatan, cara melakukan penyemprotan desinfektan dan sebagainya. Pelatihan ini dilakukan di salah satu Pedukuhan di Ngestiharjo yaitu Sumberan dengan melibatkan relawan Covid-19 yang ditujukan untuk menambah pemahaman mereka mengenai berbagai tata cara penanganan dan penggunaan perlengkapan dalam rangka penanganan Covid-19 di wilayah Desa Ngestiharjo.

Gambar 3. Pelatihan Kepada Relawan Covid-19

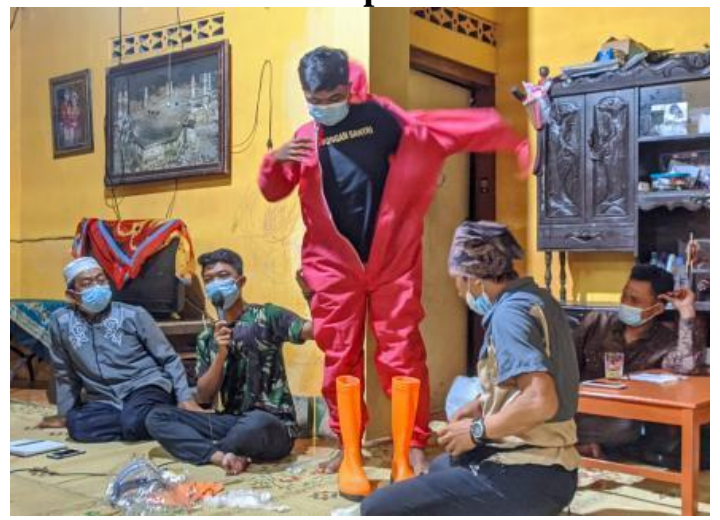

Sumber: Website Pemerintah Desa Ngestiharjo (2020)

\section{b. Kebijakan Wajib Lapor dan Isolasi}

Dalam upaya pencegahan persebaran Covid-19, Pemerintah Desa Ngestiharjo juga mewajibkan kepada seluruh pendatang untuk lapor ke RT atau Pedukuhan setempat terutama bagi mereka yang baru bepergian dari luar kota dan luar negeri. Setelah melapor, kemudian diwajibkan untuk melakukan isolasi mandiri minimal 1 minggu, apabila selama isolasi mandiri mengalami gejala Covid- 
19 maka Pemerintah Desa akan menghubungi pihak Puskesmas untuk dilakukan Test Covid-19 dan bila hasil tes positif, maka akan dilakukan tracing oleh pihak Puskesmas untuk mencari tahu awal mula dan kemungkinan persebaran ke orang lain. Bagi orang yang telah positif, Pemerintah Desa akan memberikan pilihan untuk isolasi mandiri di rumah atau di shelter milik Pemerintah Desa, namun teruntuk orang yang memiliki gejala berat tidak diperbolehkan melakukan isolasi mandiri dirumah dan diwajibkan untuk dirujuk ke shelter Pemerintah Desa atau Rumah Sakit terdekat yang memiliki fasilitas yang memadai.

Kebanyakan masyarakat Desa Ngestiharjo lebih memilih untuk melakukan isolasi di rumah karena dirasa lebih nyaman daripada isolasi di rumah sakit atau shelter. Masyarakat sekitar juga turut membantu masyarakat lainnya dengan memberikan makanan serta dukungan moril kepada mereka yang melakukan isolasi Covid-19. Pihak puskesmas biasanya melakukan kontrol pasien Covid-19 yang melakukan isolasi di rumah dalam jangka waktu tertentu sampai masa isolasi selesai. Berikut data masyarakat yang melakukan isolasi mandiri Covid-19.

Tabel 3. Jumlah Pasien Isolasi Covid-19 Desa Ngestiharjo

\begin{tabular}{|c|l|c|}
\hline No. & Tempat Isolasi & Jumlah Pasien \\
\hline 1. & Rumah & 462 \\
\hline 2. & Shelter & 10 \\
\hline 3. & Rumah Sakit & 2 \\
\hline & Jumlah & 448 \\
\hline
\end{tabular}

Sumber: Website Pemerintah Desa Ngestiharjo (2020)

Tabel di atas menunjukkan bahwa masyarakat lebih memilih melakukan isolasi mandiri di rumah yaitu sebanyak 462 orang, sisanya yaitu 10 orang di shelter dan 2 orang di rumah sakit karena memiliki penyakit bawaan yang memerlukan perawatan dan dokter khusus. Kewajiban lapor dan isolasi ini sebagai salah satu upaya untuk mengurangi penyebaran Covid-19 yang lebih luas lagi, sekaligus penanganan masyarakat yang positif agar tidak menularkan kepada masyarakat lain

\section{c. Pemakaman Pasien Covid-19 dengan Protokol Kesehatan}

Sebagai upaya pencegahan persebaran Covid-19, Pemerintah Desa Ngestiharjo juga mewajibkan penerapan protokol kesehatan dalam memakamkan pasien positif Covid-19. Pasien Covid-19 harus dimakamkan sesegera mungkin dalam waktu kurang dari 24 jam dengan melibatkan pihak rumah sakit, pelayat 
hanya boleh dari keluarga terdekat dan tidak diperbolehkan menyentuh mayat, mayat dimasukan kedalam peti dan di desinfeksi kemudian dikubur atau dikremasi sesuai dengan kepercayaannya, lalu dikuburkan dan diawasi oleh pihak Badan Penanggulangan Bencana Daerah

\section{Gambar 4. Pemakaman dengan Protokol Kesehatan}

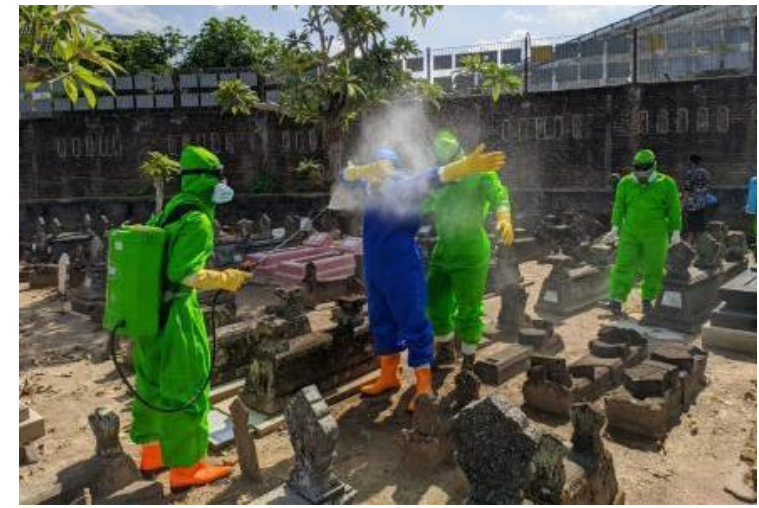

Sumber: Website Pemerintah Desa Ngestiharjo (2020)

Berdasarkan pada pedoman Gugus Tugas Percepatan Penanganan Covid19, untuk pencegahan penularan dan perlindungan masyarakat, jenazah pasien Covid-19 sebelum dikubur atau dikremasi perlu di desinfeksi menggunakan formaldehyde atau lebih dikenal dengan sebutan formalin, kemudian jenazah dimandikan oleh petugas yang berwenang dengan tetap menggunakan APD lengkap. Selanjutnya jenazah dimasukan kedalam peti mati dengan posisi miring kekanan dan shalat ghaib untuk jenazah muslim dan kemudian pemakaman dilakukan sesuai dengan ketentuan yang telah ditetapkan. Pelayat harus mematuhi protokol kesehatan dan menjaga jarak 2-3 meter dari jenazah, kemudian mencuci tangan dan muka setelah melayat dan anak kecil serta yang berusia diatas 60 tahun tidak diperkenankan untuk melayat (Gugus Tugas Percepatan Penanganan Covid19, 2020).

\section{Kesiapan (Preparedness) dan Peringatan Dini (Early Warning)}

\section{a. Koordinasi dengan Kepala Dukuh}

Pemerintah Desa Ngestiharjo juga berkoordinasi dengan Kepala Dukuh terkait dengan kegiatan-kegiatan yang akan diselenggarakan sebagai upaya penanganan persebaran Covid-19. Tidak hanya koordinasi mengenai kegiatan, pemerintah desa juga memberikan beberapa informasi mengenai penanganan 
Covid-19 kepada setiap Kepala Dukuh untuk mendukung kegiatan dan nantinya Kepala Dukuh menyampaikan kepada masyarakat di masing-masing pedukuhannya.

Berbeda dengan rapat koordinasi yang dilakukan dengan kepolisian dan BPBD Kabupaten Bantul, rapat koordinasi dengan kepala dukuh ini membahas terkait bantuan yang akan diberikan oleh Pemerintah Desa Ngestiharjo yakni bantuan peralatan yang akan digunakan untuk penanggulangan Covid-19 seperti masker dan desinfektan. Pemerintah desa tidak dapat membantu biaya operasional relawan di pedukuhan dikarenakan Pemerintah Desa Ngestiharjo sendiri telah melakukan banyak pengeluaran untuk dana desa serta penanganan Covid-19 di Desa Ngestiharjo, sehingga Pemerintah Desa Ngestiharjo hanya dapat memberikan bantuan berupa perlengkapan yang dibutuhkan oleh relawan.

\section{b. Kerjasama dengan BPBD Kabupaten Bantul}

Jika pada tahap mitigasi Pemerintah Desa Ngestiharjo bekerjasama dengan BPBD Kabupaten Bantul untuk melakukan sosialisasi dan edukasi terkait Covid19, pada tahap ini Pemdes Ngestiharjo dan BPBD Kabupaten Bantul bekerjasama dengan memanfaatkan Pusat Pengendalian Operasi (Pusdalops) yang menjadi salah satu bagian penting dalam penanggulangan bencana. Pusdalops adalah unsur pelaksana yang memiliki tugas menyelenggarakan sistem informasi dan komunikasi penanggulangan bencana yang tugasnya terbagi menjadi 3 bagian yaitu:

1) Pra Bencana: memberikan dukungan kegiatan pada saat sebelum terjadinya bencana (pengumpul, pengolah, penyaji data, dan informasi kebencanaan) secara rutin.

2) Saat Bencana: memberikan bantuan kepada posko tanggap darurat dan pelaksana kegiatan darurat.

3) Pasca Bencana: memberikan dukungan kegiatan pada saat setelah terjadinya bencana (penyedia data dan informasi khususnya dalam pelaksanaan rehabilitasi dan rekonstruksi).

Sebagai bentuk kesiapan pihak BPBD Kabupaten Bantul dalam menanggapi bencana terutama pandemi Covid-19, Pusdalops memiliki keterlibatan penting 
yakni melaksanakan koordinasi, penyiapan, penyusunan, pengolahan data, analisis potensi ancaman bencana dan rekomendasi rencana operasi. Setiap kegiatan penanggulangan bencana, dalam hal ini yakni bencana pandemi Covid-19, sangatlah penting untuk dilakukan, mengingat apabila terjadi suatu kesalahan dapat mengakibatkan dampak menjadi lebih besar, karena setiap bencana selalu memiliki potensi merusak, melukai, hingga menyebabkan kematian.

Pada bencana Pandemi Covid-19 ini, Pusdalops melakukan koordinasi kegiatan dan data-data dengan pihak-pihak yang terlibat dalam upaya penanggulangan, menyajikan data Covid-19 kepada masyarakat dan pemerintah, serta merencanakan kegiatan yang perlu dilakukan seperti pelatihan penanganan. BPBD Kabupaten Bantul melalui Pusdalops juga memberikan data update kasus Covid-19 dengan memetakan wilayah berdasarkan zona warna. Update data Covid19 yang dimiliki oleh BPBD Kabupaten Bantul tentunya berkoordinasi dengan instansi pemerintah dan disajikan dalam bentuk tabel agar mudah dipahami serta menggunakan data per RT.

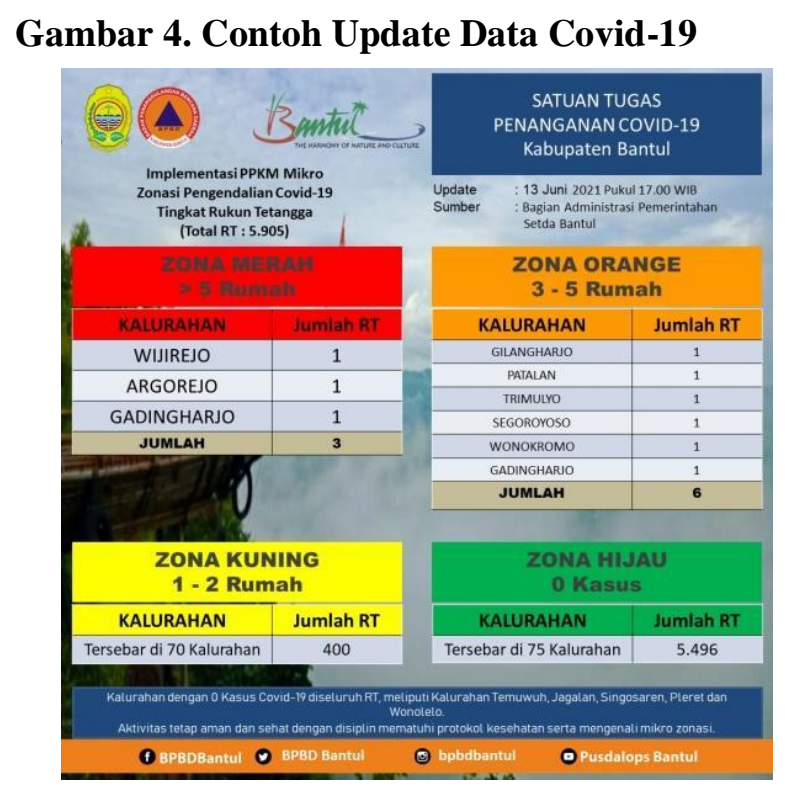

Data tersebut dibagikan oleh BPBD Kabupaten Bantul melalui media sosial kepada masyarakat dan juga instansi lainnya sebagai bentuk koordinasi. Keterangan warna pada tabel tersebut memberikan keterangan yang berbeda-beda. Warna hijau menunjukan tidak ada penularan yang terjadi di wilayah tersebut, zona kuning berarti adanya penularan lokal namun dalam skala yang terbilang masih cukup 
kecil. Pada wilayah yang berada dalam zona orange berarti perlu dilakukan pengetatan terhadap protokol kesehatan dan membatasi kegiatan masyarakat di wilayah tersebut karena di zona tersebut terdapat klaster penyebaran yang jumlahnya lebih besar dari sebelumnya. Terakhir adalah zona merah dimana untuk wilayah yang berada di dalam zona ini perlu diberlakukan karantina wilayah karena penyebaran di wilayah tersebut tergolong sangat tinggi yang mencakup pada suatu komunitas. Fungsi dari pemetaan ini adalah untuk mengelompokan suatu wilayah dengan tingkatan persebaran yang terjadi dengan melakukan tindakan dan pengawasan yang berbeda-beda di setiap zona wilayah, sehingga akan mempermudah dalam melakukan pengawasan dan pengambilan keputusan atau penanganan yang tepat terhadap wilayah tersebut.

Bencana Pandemi Covid-19 yang terjadi tidak dapat diprediksi dan belum ada tolak ukur maupun tanda-tanda yang dapat dijadikan landasan untuk membuat sistem peringatan dini pandemi, karena Pandemi Covid-19 merupakan bencana non-alam yang baru pertama kali terjadi, sehingga pemerintah baik pusat, daerah maupun desa belum dapat memberikan peringatan dini terkait adanya bencana tersebut. Bencana pandemi ini memiliki dampak yang sama dengan bencana alam pada umumnya yakni membahayakan keselamatan dan menimbulkan kerugian, sehingga langkah yang dapat diambil adalah dengan melakukan upaya-upaya untuk mengurangi persebaran, penularan dan dampak yang akan ditimbulkan.

Dari analisis di atas, Pemerintah Desa Ngestiharjo telah melakukan upayaupaya penanganan persebaran melalui beberapa cara, yaitu mitigasi, pencegahan, serta kesiapan dan peringatan dini. Mitigasi dilakukan dengan mengadakan rapat koordinasi dan sosialisasi, pembuatan peraturan dan pembangunan posko Covid19, serta pengelolaan dana desa untuk mendanai program penanganan Covid-19 dan membantu masyarakat yang terdampak. Pencegahan dilakukan dengan mengadakan pelatihan untuk relawan Covid-19, penerapan kebijakan lapor dan isolasi, dan juga penerapan protokol kesehatan dalam pemakaman korban Covid19. Sedangkan untuk kesiapan dan peringatan dini dilakukan dengan melakukan koordinasi dengan kepala dukuh di Desa Ngestiharjo dan melakukan kerjasama 
dengan BPBD Kabupaten Bantul untuk bersama-sama menangani dan mengurangi dampak yang ditimbulkan dari adanya Pandemi Covid-19.

Meskipun Pemerintah Desa Ngestiharjo telah melakukan upaya-upaya dalam penanganan persebaran Covid-19, namun masih ditemui beberapa permasalahan seperti Pemerintah Desa Ngestiharjo mengalami kekurangan dana desa, karena diawal tahun sudah digunakan untuk belanja anggaran terlebih dahulu dibandingkan dengan pembagian BLT DD, sehingga terpaksa memangkas dana kas Desa Ngestiharjo atau melakukan pinjaman untuk dana yang tidak terduga atau berlebih. Kemudian, belum adanya peringatan dini yang dapat diberikan kepada masyarakat, mengingat Pandemi Covid-19 merupakan bencana non-alam yang baru pertama kali terjadi, sehingga masih sulit menentukan peringatan seperti apa yang harus diberikan

\section{Kesimpulan}

Upaya Pemerintah Desa Ngestiharjo, Kecamatan Kasihan, Kabupaten Bantul dalam penanganan persebaran Covid-19 berdasarkan hasil penelitian dan pembahasan yang telah dilakukan melalui beberapa cara, pertama mitigasi, dimana Pemerintah Desa Ngestiharjo beserta BPBD Bantul bekerjasama melakukan sosialisasi dengan membangun kesadaran dan memberikan edukasi terkait penanggulangan Covid-19 kepada masyarakat Desa Ngestiharjo. Selain itu dibuat pula peraturan terkait penanganan Covid-19, pembangunan posko dan juga pengelolaan dana desa untuk pembuatan shelter isolasi dan membantu masyarakat miskin yang terdampak Covid-19. Kedua pencegahan, dalam hal ini, Pemerintah Desa Ngestiharjo sudah melakukan berbagai tindakan pencegahan yang diperlukan, seperti melakukan pelatihan kepada relawan Covid-19, menerapkan kebijakan wajib lapor dan isolasi bagi masyarakat yang terpapar Covid-19, serta menerapkan protokol kesehatan pada proses pemakaman pasien Covid-19. Hal tersebut dilakukan sebagai upaya untuk mencegah penyebaran virus yang lebih luas lagi. Ketiga kesiapan dan peringatan dini, dimana Pemerintah Desa Ngestiharjo melakukan koordinasi dengan kepala dukuh di Desa Ngestiharjo sebagai bentuk kesiapan dalam menjalankan kondisi Pandemi Covid-19. Koordinasi ini membahas 
bantuan yang akan diberikan Pemerintah Desa Ngestiharjo kepada masyarakat dan relawan Covid-19. Dilakukan pula bekerjasama dengan BPBD Kabupaten Bantul melalui Pusat Pengendalian Operasi (Pusdalops) sebagai bentuk kesiapan Pemdes dan BPBD Kabupaten Bantul dalam menangani Pandemi Covid-19.

Dalam pelaksanaan penanganan Pandemi Covid-19 tersebut, masih ditemui beberapa masalah seperti Pemerintah Desa Ngestiharjo mengalami kekurangan dana desa, karena di awal tahun sudah digunakan untuk belanja anggaran terlebih dahulu dibandingkan dengan pembagian BLT DD, sehingga terpaksa memangkas dana kas Desa Ngestiharjo atau melakukan pinjaman untuk dana yang tidak terduga atau berlebih. Kemudian, belum adanya peringatan dini yang dapat diberikan kepada masyarakat, mengingat Pandemi Covid-19 merupakan bencana non-alam yang baru pertama kali terjadi, sehingga masih sulit menentukan peringatan seperti apa yang harus diberikan. Oleh karena itu, perlu adanya penyediaan dana cadangan yang dapat digunakan untuk kondisi-kondisi tidak terduga yang dapat terjadi sewaktu-waktu, serta perlu dilakukan perencanaan yang lebih matang terkait pencegahan dan penanganan bencana, terutama bencana yang sulit diprediksi kedatangannya

\section{Referensi}

Akbar, I. (2021). Vaksinasi Covid 19 dan Kebijakan Negara: Perspektif Ekonomi Politik. Jurnal Academia Praja, 4(1), 11.

Dewi, W. A. F. (2020). Dampak Covid-19 Terhadap Implementasi Pembelajaran Daring di Sekolah Dasar. Edukatif: Jurnal Ilmu Pendidikan, 2(1), 5561.

Dinas Kesehatan Kabupaten Bantul. (2020). Update Data Sebaran Kasus Covid-19 di Kabupaten Bantul.

Fanisa, B., \& Ma'ruf, M. F. (2021). Pemanfaatan Dana Desa Bagi Warga Terdampak Pandemi Covid-19 (Studi Desa Bohar, Kecamatan Taman, Kabupaten Sidoarjo). Publika, 9(2), 271-282.

Gugus Tugas Covid-19. (2020). Penyiapan Fasilitas Shelter Untuk Karantina Dan Isolasi Mandiri Berbasis Masyarakat Di Masa Pandemi Covid-19. 1-7. 
Gugus Tugas Percepatan Penanganan Covid-19. (2020). Pencegahan Penularan Covid-19 Dan Perlindungan Masyarakat. 1-4.

Gumilang, G. S. (2016). Metode Penelitian Kualitatif Dalam Bidang Bimbingan dan Konseling. 2(2), 16.

Handayani, D., Hadi, D. R., Isbaniah, F., Burhan, E., \& Agustin, H. (2020). Penyakit VIrus Corona 2019. Jurnal Respirologi Indonesia, 4(2).

Kementerian Desa, Pembangunan Daerah Tertinggal, dan Transmigrasi. (2020). Peraturan Menteri Desa, Pembangunan Daerah Tertinggal, dan Transmigrasi Tentang Perubahan Kedua atas Peraturan Menteri Desa, Pembangunan Daerah Tertinggal, dan Transmigrasi Nomor 11 tahun 2019 Tentang Prioritas Penggunaan Dana Desa Tahun 2020. jdih.kemendesa.go.id

Makmun, A., \& Hazhiyah, S. F. (2020). Tinjauan Terkait Pengembangan Vaksin Covid 19. Molucca Medica, 52-59.

Moleong, L. J. (2017). Metode Penelitian Kualitatif (36th ed.). PT Remaja Rosdakarya.

Nasruddin, R., \& Haq, I. (2020). Pembatasan Sosial Berskala Besar (PSBB) dan Masyarakat Berpenghasilan Rendah. SALAM: Jurnal Sosial dan Budaya Syar-i, 7(7).

Pamungkas, B. D., Sucihati, R. N., \& Fitryani, V. (2020). Penggunaan Dana Desa Pada Masa Pandemi Covid-19 Di Kabupaten Sumbawa. Indonesian Journal of Social Sciences and Humanities, 1(2), 13.

Pemerintah Desa Ngestiharjo. (2020). Laporan Kasus Covid-19 di Desa Ngestiharjo, Kapanewon Kasihan, Kabupaten Bantul.

Putra, H. P. (2014). Pelatihan Mitigasi Bencana Kepada Anak Anak Usia Dini. 3(2), 5.

Ramli, S. (2010). Pedoman praktis manajemen bencana (Disaster Manajemen). Jakarta: Dian Rakyat.

Salman, S., Hilmi, I. L., \& Gumilar, G. G. (2021). Mitigasi Bencana Non Alam Berbasis Masyarakat Saat Dan Pasca Pandemi Covid_19 Di Kabupaten 
Karawang. Journal of Education, Humaniora and Social Sciences (JEHSS), 3(3), 1161-1169.

Sari, I. P., \& Sriwidodo, S. (2020). Perkembangan Teknologi Terkini dalam Mempercepat Produksi Vaksin Covid-19. Majalah Farmasetika, 5(5), 204.

Sasuwuk, C. H., Lengkong, F. D., \& Palar, N. A. (2021). Implementasi Kebijakan Penyaluran Bantuan Langsung Tunai Dana Desa (BLT-DD) Pada Masa Pandemi Covid-19 Di Desa Sea Kabupaten Minahasa. JAP, 11(108), 12.

Subandi. (2011). Deskripsi Kualitatif Sebagai Satu Metode Dalam Penelitian Pertunjukan. 11(2).

Subarkah, L. (2021). PPKM Berlaku, Pemda DIY Persilahkan Warga Tutup Jalan Kampung. Harian Jogja. https://jogjapolitan.harianjogja.com

Sudirman, F. A., \& Rifai, R. (2021). Private Sector Contribution in Achieving the Sustainable Development Goals (SDGs) 7 in Kendari, Indonesia. International Journal of Qualitative Research, 1(1), 55-60. https://doi.org/10.47540/ijqr.v1i1.319

Sudirman, F. A., Upe, A., \& La Ode Herman, F. T. S. (2021). Corporate Social Responsibility (CSR) Contribution to Achieve Sustainable Development Goals (SDGs) in Southeast Sulawesi. Proceedings of the 11th Annual International Conference on Industrial Engineering and Operations Management Singapor. http://www.ieomsociety.org/singapore2021/papers/616.pdf

Telaumbanua, D. (2020). Urgensi Pembentukan Aturan Terkait Pencegahan Covid19 di Indonesia. QALAMUNA: Jurnal Pendidikan, Sosial, Dan Agama, 12(1), 59-70. 